\title{
Inhibition of Angiotensin-Converting Enzyme Activity by a Partially Purified Fraction of Gynura procumbens in Spontaneously Hypertensive Rats
}

\author{
See-Ziau Hoe ${ }^{a}$ Mohd Yusof Kamaruddin ${ }^{b}$ Sau-Kuen Lam ${ }^{a}$ \\ Departments of a Physiology and ${ }^{b}$ Molecular Medicine, Faculty of Medicine, University of Malaya, \\ Kuala Lumpur, Malaysia
}

\section{Key Words}

Gynura procumbens $\cdot$ Hypotensive $\cdot$ Angiotensin-converting enzyme, inhibition

\begin{abstract}
Objectives: To investigate the hypotensive and angiotensinconverting enzyme (ACE) inhibitory activities of a partially purified fraction (FA-I) of the leaves of Gynura procumbens and to qualitatively analyse the putative compounds present in the fraction. Materials and Methods: The hypotensive effect of FA-I was tested in both spontaneously hypertensive rats (SHR) and normotensive Wistar-Kyoto rats (WKY) by an intravenous administration of $0-10 \mathrm{mg} / \mathrm{kg}$ of the FA-I. Administration of captopril $(20 \mu \mathrm{g} / \mathrm{kg})$ served as the control. In vitro $0.0-2.0 \mathrm{mg} / \mathrm{ml} \mathrm{FA-I} \mathrm{was} \mathrm{added} \mathrm{to} \mathrm{a} \mathrm{mixture} \mathrm{of} \mathrm{ACE}$ and hippuryl-L-histidyl-L-leucine and assayed by a modification of the colourimetric method of Hurst and Lovell-Smith. All blood pressure measurements were monitored by the Macintosh MacLab set-up. ACE activity was measured by an in vitro assay in which the enzymatic cleavage of hippuryl-Lhistidyl-L-leucine to form histidyl-leucine and hippurate was determined colourimetrically by a cyanuric chloride/dioxane reagent. Results: The FA-I produced a marked dose-dependent reduction in mean arterial pressure (MAP) in SHR and WKY rats, with an $\mathrm{ED}_{50}$ of 1.09 and $1.05 \mathrm{mg} / \mathrm{kg}$, respec-
\end{abstract}

tively $(p<0.01)$. Furthermore, FA-I at $10 \mathrm{mg} / \mathrm{kg}$ strongly inhibited the angiotensin I-induced rise in MAP $(p<0.01)$. This response was comparable to that of captopril at $20 \mu \mathrm{g} / \mathrm{kg}$. In the in vitro assay, ACE activity was inhibited with an $\mathrm{IC}_{50}$ of $0.8 \mathrm{mg} / \mathrm{ml}$. The qualitative phytochemical analysis of FA-I indicated the presence of glycoconjugates and peptides. Conclusion: These results suggest that the hypotensive effect of G. procumbens may be due, in part, to the glycoconjugated or peptidal substances found in FA-I that exhibit an inhibitory effect on ACE.

Copyright $\odot 2007$ S. Karger AG, Basel

\section{Introduction}

Angiotensin-converting enzyme (ACE), or kininase II, (EC 3.4.15.1) is a dipeptidyl carboxyl metallopeptidase that is widely distributed in most mammalian organs, especially in the lung [1]. It is well recognised that ACE plays an important role in the renin-angiotensin system (RAS) and consequently in the regulation of blood pressure (BP), water-electrolyte balance, vascular function and cell growth [2]. In the RAS, ACE cleaves the C-terminal dipeptide His-Leu from the biologically inactive decapeptide angiotensin I (Ang I) to produce a potent vasoconstrictor, angiotensin II (Ang II) [1]. Apart from its

\section{KARGER}

Fax +4161306 1234

E-Mail karger@karger.ch

www.karger.com
(C) 2007 S. Karger AG, Basel

$1011-7571 / 07 / 0163-0203 \$ 23.50 / 0$

Accessible online at:

www.karger.com/mpp
Sau-Kuen Lam

Department of Physiology, Faculty of Medicine, University of Malaya 50603 Kuala Lumpur (Malaysia)

Tel. +60 37967 4907, Fax +60 379674775

E-Maillam@ummc.edu.my 
vasopressor action, Ang II also increases the synthesis and release of aldosterone from the adrenal cortex, which causes sodium and water retention in the distal tubules [2]. In addition, in the kallikrein-kinin system, ACE mediates the hydrolysis of bradykinin, a substance that lowers BP [3] by promoting vasodilatation [4] and natriuresis [5]. Inhibition of ACE decreases the formation of Ang II and the degradation of bradykinin and subsequently brings about increased diuresis and a fall in BP. Therefore, ACE inhibition is considered to be an effective therapeutic approach to the treatment of cardiovascular diseases, and many synthetic ACE inhibitors such as captopril, enalapril, lisinopril and ramipril are widely used clinically for the treatment of hypertension [6]. In addition to the synthetic drugs, other putative ACE inhibitors isolated from natural resources, such as tannins [7], flavonoids [8] and peptides/amino acids [9-11], have also been developed.

Gynura procumbens Merr. (Compositae), a fast growing herbaceous plant, is widely found in Southeast Asia. In folk medicine, the plant is generally used for treating kidney diseases, rashes and fever [12] and for hypertension. Preliminary studies from this laboratory have shown that an aqueous fraction (FA) of G. procumbens decreases the mean arterial pressure (MAP) of rats [13]. In the present study, a purer fraction of FA (FA-I) has been obtained and the hypotensive activity of FA-I on spontaneously hypertensive (SHR) rats is investigated. The effect of FA-I on ACE activity is also examined in vivo and in vitro in an attempt to elucidate the mechanism of the hypotensive effect. In addition, a qualitative phytochemical analysis of FA-I is performed.

\section{Materials and Methods}

\section{Chemicals}

ACE from rabbit lung, captopril, hippuryl-L-histidyl-L-leucine (HHL) and hippuric acid were obtained from Sigma Chemical Co., St. Louis, Mo., USA. Heparin was purchased from Leo Pharmaceutical Products, Ballerup, Denmark, while thin layer chromatography (TLC) plates (silica gel $60 \mathrm{~F}_{254}$ ) were purchased from Merck KGaA (Darmstadt, Germany). Other chemicals and the solvents of the analytical grade were obtained from $\mathrm{R} \& \mathrm{M}$ Marketing, Essex, UK.

\section{Plant Material}

Whole plants of $G$. procumbens, excluding the roots, were collected from the Southern part of Peninsular Malaysia and authenticated at the Institute of Biological Sciences, University of Malaya. A voucher specimen (KLU 44538) was deposited at the herbarium at the Rimba Ilmu, University of Malaya.
Extraction and Fractionation of Plant Material

Leaves from the fresh plant were cleaned and dried in an oven at $40^{\circ} \mathrm{C}$ and then ground to powder. A crude ethanolic extract was made by macerating the powder $(250 \mathrm{~g})$ with $96 \%$ ethanol at room temperature for $72 \mathrm{~h}$. The extract was concentrated to dryness in vacuo, and this resulted in a gummy residue that was then reconstituted in $80 \%$ aqueous ethanol. The resulting solution was partitioned with hexane. The aqueous ethanolic phase of the partition was collected and subjected to evaporation in vacuo removing the ethanol but leaving behind an aqueous solution that contained an ethanol-soluble precipitate that was filtered out. The precipitate-free aqueous solution was then further partitioned against water-saturated $n$-butanol. The aqueous phase from this partition was collected and lyophilised to obtain the FA (7.5 g).

\section{Sephadex LH-20 Gel Filtration Chromatography}

The FA was further purified by passing it through a column containing Sephadex LH-20 gel using water as the eluent. This resulted in the isolation of a purer fraction (FA-I).

\section{Animals}

SHR and control normotensive Wistar-Kyoto (WKY) rats, weighing between 250 and $300 \mathrm{~g}$, were obtained from the Experimental Animal Centre, University of Malaya. They were kept under standard conditions and given tap water and standard rat chow (Gold Coin Animal Feed, Malaysia) ad libitum. All procedures were approved by the University of Malaya Medical Centre Animal Ethics Committee.

\section{Measurement of BP}

The rats were anaesthetised with sodium pentobarbitone $(60 \%, \mathrm{w} / \mathrm{v}), 50 \mathrm{mg} / \mathrm{kg}$, by intraperitoneal injection. The right jugular vein, left carotid artery and trachea were surgically exposed. A heparinised polyethylene cannula was inserted into the carotid artery for continuous monitoring of the BP via a pressure transducer connected to the Macintosh MacLab set-up (AD Instruments Pty. Ltd., Australia). The jugular vein was cannulated with heparinised polyethylene tubing for intravenous injections of the test solutions. The trachea was cannulated to facilitate spontaneous respiration. The animal was kept warm $\left(35 \pm 2{ }^{\circ} \mathrm{C}\right)$ with a heating lamp throughout the experiment. The set-up was allowed to equilibrate for at least $30 \mathrm{~min}$ prior to the commencement of the experiments. After the equilibration period, the SHR rats $(\mathrm{n}=6)$ were injected with FA-I that was dissolved in normal saline, at different doses $(0-10 \mathrm{mg} / \mathrm{kg})$. The BP was allowed to return to the resting level before each subsequent injection was given. The average recovery period after each injection was about 30 min. Changes in the BP due to the administration of the extracts were obtained by calculating the difference between the $\mathrm{BP}$ before and the lowest BP recorded after the injections. For the controls, WKY rats $(n=6)$ were similarly injected with the same doses of FA-I. The MAP was calculated using the formula: $\mathrm{MAP}=\mathrm{DBP}+1 / 3(\mathrm{SBP}-\mathrm{DBP})$, where $\mathrm{DBP}$ is diastolic BP and SBP systolic BP.

\section{In vivo Assay for ACE Inhibitory Activity}

The ACE inhibitory activity of FA-I was assayed in vivo by the method of Motoi and Kodama [10]. Briefly, SHR rats were anaesthetised and their carotid arteries and jugular veins ex- 
Fig. 1. Effect of FA-I of G. procumbens on MAP of SHR and WKY rats. Values are means $\pm \operatorname{SEM}(n=6) .{ }^{\mathrm{a}} \mathrm{p}<0.01 ;{ }^{\mathrm{b}} \mathrm{p}<0.001$ (compared with controls); ${ }^{\mathrm{c}} \mathrm{p}<0.05 ;{ }^{\mathrm{d}} \mathrm{p}<$ 0.01 (compared with the respective WKY group).

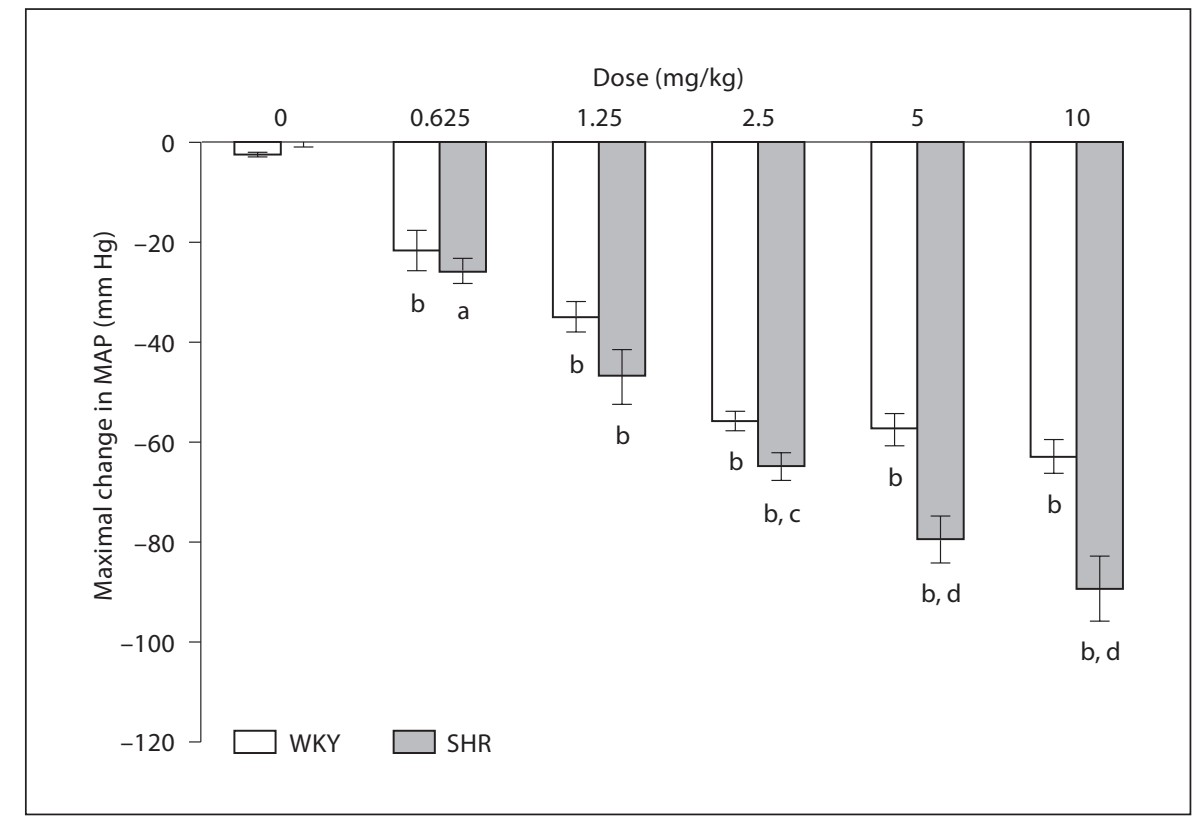

posed as above. Ang I ( $40 \mu \mathrm{g} / \mathrm{kg})$ was administered intravenously through the jugular vein and the elevation in MAP served as control. When the BP returned to baseline, Ang I and an effective dose of FA-I (10 mg/kg) were injected simultaneously (combined administration). As soon as the BP returned to baseline, the same dose of Ang I alone was given. The hypertensive responses of Ang I administered with and without FA-I were compared. The experiment was repeated using captopril $(20 \mu \mathrm{g} / \mathrm{kg})$ instead of FA-I.

\section{In vitro Assay of ACE Inhibitory Activity}

The ACE inhibitory activity of FA-I was also assayed in vitro by the colourimetric method of Hurst and Lovell-Smith [14], with some modifications. In this assay, ACE, alone or together with different concentrations $(0-2.0 \mathrm{mg} / \mathrm{ml})$ of FA-I, was added to a solution containing a synthetic substrate, HHL. The cleaving action of ACE on the substrate would release hippurate, which was then reacted with cyanuric chloride in dioxane to yield a coloured complex that was quantifiable spectrophotometrically by absorbance at $382 \mathrm{~nm}$.

\section{Phytochemical Screening}

Preliminary phytochemical screening on FA-I was performed using TLC plates. The TLC plates were developed twice in a mobile phase that consisted of $n$-butanol:acetic acid:water $(4: 1: 5 \mathrm{v} / \mathrm{v}$, upper layer). The separated components on the TLC plates were detected by various chemical spray reagents $[15,16]$.

\section{Statistical Analysis}

All values are expressed as mean \pm SEM. Statistical differences were evaluated by Student's t test, analysis of variance and Duncan's new multiple-range test. A probability level of $\mathrm{p}<0.05$ is considered to be significantly different.

ACE Inhibitory Effect of Gynura

procumbens Extract

\section{Results}

Effect of FA-I on the MAP of SHR and WKY Rats

Intravenous bolus injections of FA-I $(0-10 \mathrm{mg} / \mathrm{kg})$ caused a dose-dependent significant reduction in MAP in both anaesthetised SHR and WKY rats ( $<<0.01$; fig. 1). The reduction in MAP was significantly greater in the SHR than in the WKY rats, especially at higher doses $(p<0.05)$. The $E_{50}$ of FA-I in SHR and WKY were 1.09 and $1.05 \mathrm{mg} / \mathrm{kg}$, respectively.

\section{In vivo ACE Inhibition}

The MAP of SHR was elevated by $46.3 \pm 5.1 \mathrm{~mm} \mathrm{Hg}$ (control) after an intravenous injection of Ang I (fig. 2a). The Ang I-induced elevation of MAP was significantly reduced to $15.7 \pm 4.6 \mathrm{~mm} \mathrm{Hg}$ when given the combined administration $(\mathrm{p}<0.01)$. However, when Ang I alone was given again, the degree of the elevation of MAP was still significantly reduced $(\mathrm{p}<0.05)$. Similar observations were also made when captopril $(20 \mu \mathrm{g} / \mathrm{kg})$, a well-known antihypertensive agent with known ACE inhibitory activity [17], was injected together with Ang I (fig. 2a).

\section{In vitro ACE Inhibition}

In vitro ACE activity was inhibited in a concentrationdependent manner with the activity being almost completely inhibited at $2.0 \mathrm{mg} / \mathrm{ml}$ of FA-I. The $\mathrm{IC}_{50}$ value of FA-I was found to be $0.8 \mathrm{mg} / \mathrm{ml}$ (fig. 2b). 
Fig. 2. Effect of FA-I on ACE activity. a Effect of FA-I on Ang I-induced hypertension in vivo. Values are means \pm SEM $(\mathrm{n}-=6) .{ }^{*} \mathrm{p}<0.05$ and ${ }^{* *} \mathrm{p}<0.01$ denote that the hypertensive effect of Ang I is significantly reduced compared to the controls. $\mathbf{b}$ Inhibition of ACE activity by FA-I in vitro. Values are means $\pm \operatorname{SEM}(n=3)$. ${ }^{*} \mathrm{p}<0.05,{ }^{* *} \mathrm{p}<0.01$ and ${ }^{* * *} \mathrm{p}<0.001 \mathrm{de}-$ note that the activity of ACE is significantly reduced compared to the controls $\left(\mathrm{IC}_{50}=0.8 \mathrm{mg} / \mathrm{ml}\right)$.
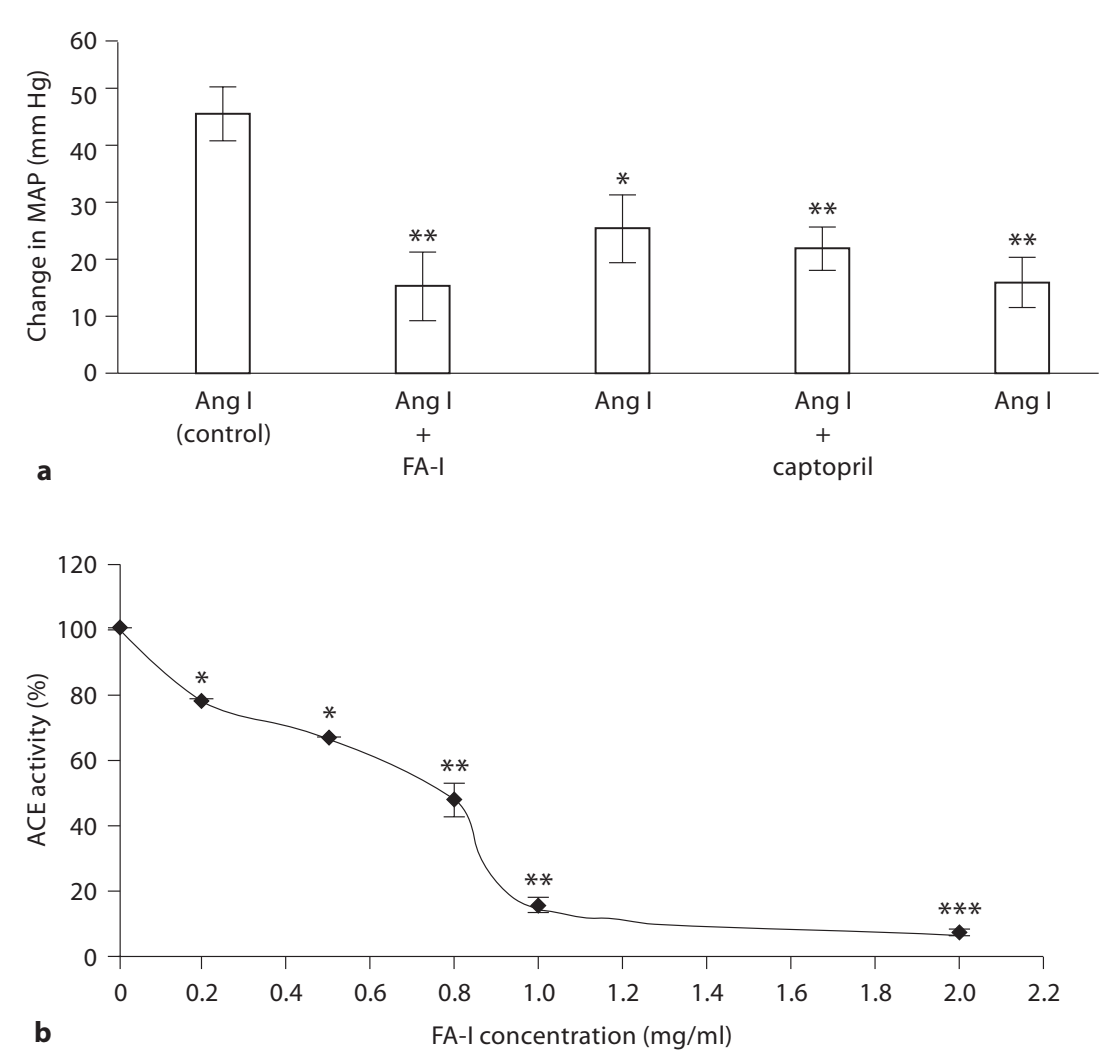

\section{Phytochemical Screening}

The qualitative phytochemical analysis of FA-I using TLC revealed the presence of glycoconjugates as detected by the aniline-diphenylamine-phosphoric reagent and peptides as detected by the ninhydrin reagent (fig. 3).

\section{Discussion}

These studies demonstrate that a partially purified fraction (FA-I) of the leaves of G. procumbens is able to cause a dose-dependent fall in the MAP of both hypertensive and normotensive rats (fig. 1), probably by inhibiting the action of ACE as shown by the in vivo and in vitro studies.

It is well established that Ang II, the effector peptide of the RAS, plays a pivotal role in cardiovascular and electrolyte and fluid homeostasis, and has been implicated as a causative factor in the development of hypertension [2]. Indeed, inhibiting the RAS with an ACE inhibitor is considered to be one of the successful forms of treatment

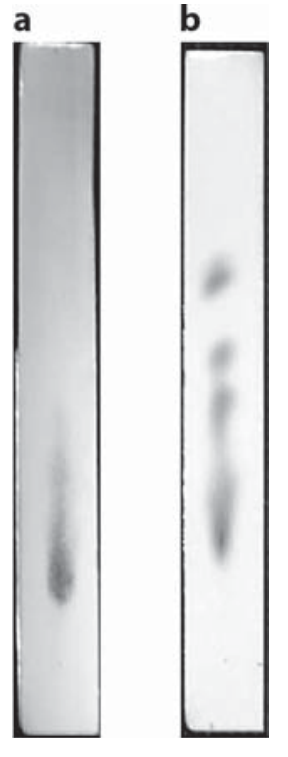

Fig. 3. TLC of FA-I. The developed TLC plates were sprayed with aniline-diphenylamine-phosphoric acid (a) and ninhydrin reagents (b), to detect the presence of glycoconjugates and peptides, respectively. 
of hypertension and other cardiovascular conditions [6]. Although several synthetic ACE inhibitors are now widely available for use as antihypertensive drugs, they have been known to cause some undesirable side effects such as postural hypotension, cough, renal failure and angiooedema [18]. Currently, many studies are being done to search for more suitable antihypertensive agents, including ACE inhibitors, from natural products [7-11]. Findings from these studies may open up the possibilities of more alternatives with ACE inhibitory effects but better drug profiles and less adverse side effects.

In the present in vivo study, intravenous injection of Ang I produces an increase in MAP probably due to the action of ACE, which converts Ang I to Ang II, a potent vasoconstrictor. This vasopressor response of Ang I is inhibited by $30.65 \pm 10.10 \mathrm{~mm} \mathrm{Hg}$ when given simultaneously with FA-I. This degree of inhibition appears to be comparable to that obtained with captopril (23.92 \pm 7.8 $\mathrm{mm} \mathrm{Hg}$; fig. 2a). In order to examine the extent of the ACE inhibitory effect of FA-I, Ang I alone was injected again after the combined administration. The degree of elevation of MAP was found to be still significantly reduced (fig. 2a), indicating that the inhibitory action of FA-I is probably long acting. These observations are confirmed by the direct inhibition of ACE activity by FA-I as shown by the in vitro studies. Thus, FA-I appears to contain some very effective inhibitory principles against ACE activity. Furthermore, the long-acting effect of FA-I may also suggest possible antagonistic actions on Ang II receptors, similar to that of losartan, an Ang II receptor antagonist, with long-lasting effect [19].

Using phytochemical screening techniques, the possible hypotensive compounds in FA-I are found to be gly- coconjugates and/or peptides in nature. In the literature, various peptides, isolated from diverse plant and animal sources, have been shown to possess antihypertensive activities, and most of them appear to act by inhibiting ACE activity [20]. The sources of ACE inhibitory peptides include sake [21], tofuyo [22], wheat gliadin [10], spinach rubisco [9], rapeseed [23] and sunflower seed [24]. Indeed, the development of ACE inhibitors was heralded by the discovery of bradykinin-potentiating factors, peptides that inhibit kininase II, in the venom of the Brazilian viper Bothrops jararaca [25]. These peptides have been used as model substances in the discovery of most of the synthetic ACE inhibitors [17].

In the present investigation, although the active component(s), either the glycoconjugates or the peptides, or both, in FA-I are yet to be finally identified, the conclusive findings of the BP-lowering and ACE-inhibitory effects of this fraction from $G$. procumbens may further help strengthen the anecdotal observations that this plant does indeed possess active principles that affect BP.

\section{Conclusion}

The results of this study demonstrate that a partially purified fraction, FA-I, from G. procumbens appears to be able to bring about hypotensive effect in SHR and WKY rats by acting through inhibition of the ACE. The findings also suggest that the putative hypotensive agents seem to be glycoconjugated or peptidal substances in nature. The exact structure of the candidate compound awaits further investigation.

\section{References}

1 Soffer RL: Angiotensin-converting enzyme and the regulation of vasoactive peptides. Ann Rev Biochem 1976;45:73-94.

2 Kim S, Iwao H: Molecular and cellular mechanisms of angiotensin II-mediated cardiovascular and renal diseases. Pharmacol Rev 2000;52:11-34.

3 Erdox EG: The angiotensin I converting enzyme. Fed Proc 1977;36:1760-1765.

4 Vanhoutte DM: Endothelium and control of vascular function: state of the art lecture. Hypertension 1989;13:658-667.

5 Stein JH, Congbalay RC, Karsh DL, Osgood RW, Ferris TF: The effect of bradykinin on proximal tubular sodium reabsorption in the dogs: evidence for functional nephron heterogeneity. J Clin Invest 1972;51:1709-1721.
6 Wong J, Patel RA, Kowey PR: The clinical use of angiotensin-converting enzyme inhibitors. Prog Cardiovasc Dis 2004;47:116-130.

-7 Liu JC, Hsu FL, Tsai JC, Chan P, Liu JYH, Thomas GN, Tomlison B, Lo MY, Lin JY: Antihypertensive effects of tannins isolated from traditional Chinese herbs as non-specific inhibitors of angiotensin converting enzyme. Life Sci 2003;73:1543-1555.

8 Kameda K, Takaku T, Okuda H, Kimura Y, Okuda T, Hatano T, Agata I, Arichi S: Inhibitory effects of various flavonoids isolated from leaves of persimmon on angiotensinconverting enzyme activity. J Nat Prod 1987; 50:680-683.
-9 Yang Y, Marczak ED, Yokoo M, Usui H, Yoshikawa, M: Isolation and antihypertensive effect of angiotensin I-converting enzyme (ACE) inhibitory peptides from spinach Rubisco. J Agric Food Chem 2003;51:48974902.

10 Motoi $\mathrm{H}$, Kodama T: Isolation and characterization of angiotensin I-converting enzyme inhibitory peptides from wheat gliadin hydrolysate. Nahrung 2003;47:352-356.

11 Suetsuna K, Maekawa K, Chen JR: Antihypertensive effects of Undaria pinnatifida (wakame) peptide on blood pressure in spontaneously hypertensive rats. J Nutr Biochem 2004;15:267-272. 
12 Perry LM: Medicinal Plants of East and Southeast Asia. Attributed Properties and Uses. Cambridge, MIT Press, 1980.

13 Hoe SZ, Lam SK: Hypotensive activity of an aqueous fraction of Gynura procumbens and possible mechanisms of action. Circ J 2005; 69(suppl 1):348.

14 Hurst PL, Lovell-Smith CJ: Optimized assay for serum angiotensin-converting enzyme activity. Clin Chem 1981;27:2048-2052.

15 Houghton PJ, Raman A: Laboratory Handbook for the Fractionation of Natural Extracts. London, Chapman \& Hall, 1998.

16 Anderson K, Li SC, Li YT: Diphenylamineaniline-phosphoric acid reagent, a versatile spray reagent for revealing glycoconjugates on thin layer chromatography plates. Anal Biochem 2000;287:337-339.

17 Cushman DW, Ondetti MA: History of the design of captopril and related inhibitors of angiotensin converting enzyme. Hypertension 1991; 17:589-592.
18 Brown NJ, Vaughan DE: Angiotensin-converting enzyme inhibitors. Circulation 1998; 97:1411-1420.

19 Christen Y, Waeber B, Nussberger J, Porchet M, Borland RM, Lee RJ, Maggon K, Shum L, Timmermans PB, Brunner HR: Oral administration of $\mathrm{DuP} 753$, a specific angiotensin II receptor antagonist, to normal male volunteers: inhibition of pressor response to exogenous angiotensin I and II. Circulation 1991;83:1333-1342.

20 Rutherfurd-Markwick KJ, Moughan PJ: Bioactive peptides derived from food. J AOAC Int 2005;88:955-966.

21 Saito Y, Wanezaki K, Kawato A, Imayasu S: Antihypertensive effects of peptide in sake and its by-products on spontaneously hypertensive rats. Biosci Biotechnol Biochem 1994; 58:812-816.
22 Kuba M, Tanaka K, Tawata S, Takeda Y, Yasuda M: Angiotensin I-converting enzyme inhibitory peptides isolated from tofuyo fermented soybean food. Biosci Biotechnol Biochem 2003;67:1278-1283.

23 Marczak ED, Usui H, Fujita H, Yang Y, Yokoo M, Lipkowski AW, Yoshikawa M: New antihypertensive peptides isolated from rapeseed. Peptides 2003;24:791-798.

24 Megias C, del Mar Yust M, Pedroche J, Lquari H, Giron-Calle J, Alaiz M, Millan F, Vioque $\mathrm{J}$ : Purification of an ACE inhibitory peptide after hydrolysis of sunflower (Helianthus annuus L.) protein isolates. J Agric Food Chem 2004;52:1928-1932.

25 Ondetti MA, Williams NJ, Sabo EF, Pluscec J, Weaver ER, Kocy O: Angiotensin-converting enzyme inhibitors from the venom of $\mathrm{Bo}$ throps jararaca: isolation, elucidation of structure, and synthesis. Biochemistry 1971; 10:4033-4039. 